\title{
Performance of Citrus Scion Cultivars and Rootstock in a High-density Planting
}

\author{
T.A. Wheaton, W.S. Castle, J.D. Whitney, and D.P.H. Tucker \\ Citrus Research and Education Center, University of Florida, Institute of \\ Food and Agricultural Sciences, 700 Experiment Station Road, Lake \\ Alfred, FL 33850
}

Additional index words. tree spacing, yield efficiency

Abstract. 'Hamlin' and 'Valencia' oranges [Citrus sinensis (L.) Osb.], 'Murcott' tangor (C. reticulata Blanco $\times C$. sinensis), and 'Redblush' grapefruit ( $C$. paradisi Macf.) on 15 rootstock and own-rooted cuttings were planted at a $1.5 \times 3.3-\mathrm{m}$ spacing providing a density of 2020 trees/ha. Growth rate, productivity, and fruit quality varied among the scion and stock combinations. Combinations of moderate vigor and precocious fruiting performed better than very vigorous or dwarfing materials. Several freezes slowed canopy development and delayed production. Most trees had filled their allocated canopy space 7 years after planting. At that age, the orange trees yielded 23 to $75 \mathrm{t}^{\prime} \mathrm{ha}^{-1}$. Scion and stock combinations with desirable vigor and fruiting characteristics were satisfactory in this high-density planting. However, there appears to be little advantage of high tree density under Florida conditions, and moderate densities of fewer than 1000 trees/ha may be preferable.

Increased understanding of the importance of canopy development (Wheaton et al., 1978) and the results of local spacing experiments (Koo and Muraro, 1982; Wheaton et al., 1986) have resulted in a trend to plant Florida citrus orchards at greater tree densities than practiced previously. New plantings of 300 trees/ha are common with rows generally 6 to $8 \mathrm{~m}$ apart and trees spaced 3 to 5 $\mathrm{m}$ in the row. At maturity, trees develop a hedgerow 4 to $6 \mathrm{~m}$ high and 5 to $6 \mathrm{~m}$ across. Much higher tree densities are not common commercially, but they have been tried experimentally in other areas. In Japan, Tachibana and Nakai (1989) compared densities of 1250 to 10,000 trees/ha. Time required to reach maximum yield ranged from 4 years for the highest density to 14 years at the lowest density. Maximum yield was between 50 to $70 \mathrm{t}^{\mathrm{h}} \mathrm{ha}^{-1}$ and was similar for all densities. Canopy development (leaf area index) was the principal factor that influenced yield variation. Cumulative yield of dwarf orange trees planted at 667 to 5000 trees/ha in Australia increased with increasing tree density for the first years of production (Hutton and Cullis, 1981). An average annual yield of 60 $\mathrm{t} \cdot \mathrm{ha} \mathrm{a}^{-1}$ was obtained for 6-year-old 'Valencia' orange trees at densities of 2250 to 5000 trees/ha (Cary, 1981). Other reports of experimental plantings with tree densities in

Received for publication 24 Sept. 1990. Florida Agricultural Experiment Station Journal Series no. $\mathrm{R}-01043$. The cost of publishing this paper was defrayed in part by the payment of page charges. Under postal regulations, this paper therefore must be hereby marked advertisement solely to indicate this fact. the 1000- to 5000-trees/ha range were summarized by Cary (1981); these plantings generally produced $<60 \mathrm{t} \cdot \mathrm{ha}^{-1}$.

Previous experiments in Florida demonstrated the feasibility of growing citrus at moderate densities up to 890 trees/ha (Koo and Muraro, 1982; Wheaton et al., 1986). The purpose of our research was to: 1) determine the horticultural adaptability of four commercial scion cultivars on 15 rootstock and of rooted cuttings of each scion for trees planted at a density of 2020 trees/ha and maintained small and 2) establish the potential of closely spaced citrus trees for rapid development of canopy volume and fruiting potential per unit of land area.

Trees of the four cultivars on each rootstock (Table 1) were produced in a green- house and planted in the field in 1981. A split plot experiment and analysis of variance (ANOVA) statistics were used with four replications, with cultivar as the main plot and rootstock as the subplot. Field plots were four $\times$ four trees, with data taken from the center four of the 16 trees. They were planted $1.5 \mathrm{~m}$ in the row and $3.3 \mathrm{~m}$ between rows and were irrigated and fertigated as required to maintain optimal soil water and nutrient levels using one microsprinkler per two trees. Trees were mechanically hedged and topped during Summer 1987 and hedged again in 1989 to maintain a $1.5-\mathrm{m}$ alley between rows and a $2.5-\mathrm{m}$ tree height. Thus, the canopy size allocated for each tree was $1.5 \mathrm{~m}$ in the row, $1.8 \mathrm{~m}$ across the row, and $2.5 \mathrm{~m}$ in height, providing $6.8 \mathrm{~m}^{3}$ of canopy volume per tree and $13,635 \mathrm{~m}^{3} \cdot \mathrm{ha}^{-1}$ at containment size.

The planting was planned to allow either small equipment to move in the $1.5-\mathrm{m}$ alley between rows or for specially designed overthe-row equipment. Actually, small, tractormounted equipment was used in the alley for spraying, herbicide application, and hedging and topping. Spaces were left at the end of every two plots to provide access for fruit handling equipment. In a commercial planting, other arrangements for fruit handling would be required.

Tree growth was reduced and containment size was not attained in the projected 3 to 5 years because of damaging freezes during the 4 years after planting. Fruit production began in the 5 th year, and many trees reached containment size at 7 years. Yield was measured by harvesting and weighing fruit from each plot. Fruit characteristics measured included average fruit weight, juice content, total acidity, and soluble solids concentration (SSC) from samples of $\approx 12 \mathrm{~kg} / \mathrm{plot}$. Yield comparisons were based on cumulative yield from 5 to 8 years after planting. Maximum yield occurred during the 198889 season (trees were 7 years old), and data

Table 1. Rootstock used for 'Hamlin' and 'Valencia' sweet oranges, 'Redblush' grapefruit, and 'Murcott' tangor.

\begin{tabular}{ll}
\hline \hline Common name & \multicolumn{1}{c}{ Scientific name } \\
\hline Carrizo citrange & $\begin{array}{c}\text { Citrus sinensis (L.) Osb. x } \\
\text { Poncirus trifoliata (L.) Raf. }\end{array}$ \\
Changsha mandarin & C. reticulata Blanco \\
Cleopatra mandarin & C. reticulata \\
Flying Dragon trifoliate & P. trifoliata \\
Jacobsen trifoliate & P. trifoliata \\
Koethen sweet orange $x$ & \\
Rubidoux trifoliate & (See Carrizo) \\
Macrophylla & C. macrophylla Wester \\
Milam & C. jambhiri Lush., variant \\
Morton citrange & (See Carrizo) \\
Own-rooted & Rooted cuttings of cach scion cultivar \\
Palestine sweet lime & C. limettioides Tan. \\
Rangpur $x$ Troyer citrange & C. limonia Osb. $\times$ (see Carrizo) \\
Rubidoux trifoliate & P. trifoliata \\
Rusk citrange & (See Carrizo) \\
Sour orange & C. aurantium L. \\
Swingle citrumelo & C. paradisi Macf. x $P$. trifoliata \\
\hline
\end{tabular}


Table 2. Effect of rootstock on cumulative yield for 4 years. 1986-87 to 1989-90.

\begin{tabular}{|c|c|c|c|c|c|c|c|c|}
\hline \multirow[b]{3}{*}{ Rootstock } & \multicolumn{8}{|c|}{ Cultivar } \\
\hline & \multicolumn{2}{|c|}{$\begin{array}{c}\text { Hamlin } \\
\text { sweet orange }\end{array}$} & \multicolumn{2}{|c|}{$\begin{array}{c}\text { Valencia } \\
\text { sweet orange }\end{array}$} & \multicolumn{2}{|c|}{$\begin{array}{l}\text { Redblush } \\
\text { grapefruit }\end{array}$} & \multicolumn{2}{|c|}{$\begin{array}{c}\text { Murcott } \\
\text { tangor }\end{array}$} \\
\hline & $t \cdot h a^{-1}$ & Rank & $\mathrm{t} \cdot \mathrm{ha}^{-1}$ & Rank & $t \cdot h a^{-1}$ & Rank & thas -1 & Rank \\
\hline Carrizo & 143 & 4 & 114 & 3 & 162 & 6 & 100 & 6 \\
\hline Changsha & 103 & 10 & 58 & 16 & 179 & 4 & 110 & 2 \\
\hline Cleopatra & 54 & 16 & 69 & 13 & 50 & 16 & 93 & 7 \\
\hline Flying Dragon & 85 & 14 & 67 & 14 & 118 & 13 & 47 & 15 \\
\hline $\begin{array}{l}\text { Jacobsen } \\
\text { Koethen } x\end{array}$ & 126 & 5 & 79 & 11 & 138 & 9 & 53 & 13 \\
\hline Rubidoux & 159 & 1 & 114 & 5 & 233 & 1 & 110 & 3 \\
\hline Macrophylla . & 113 & 9 & 97 & 7 & 129 & 11 & 46 & 16 \\
\hline Milam & 67 & 15 & 65 & 15 & 91 & 15 & 78 & 10 \\
\hline Morton & 156 & 2 & 126 & 1 & 232 & 2 & 109 & 4 \\
\hline $\begin{array}{l}\text { Own-rooted } \\
\text { Palestine }\end{array}$ & 91 & 11 & 71 & 12 & 120 & 12 & 91 & 8 \\
\hline sweet lime & 119 & 7 & 107 & 6 & 116 & 14 & 51 & 14 \\
\hline Rangpur X & & & & & & & & \\
\hline Troyer & 86 & 12 & 86 & 10 & 171 & 5 & 78 & 11 \\
\hline Rubidoux & 86 & 13 & 94 & 9 & 138 & 10 & 60 & 12 \\
\hline Rusk & 118 & 8 & 114 & 4 & 220 & 3 & 88 & 9 \\
\hline Sour orange & 121 & 6 & 96 & 8 & 158 & 7 & 120 & 1 \\
\hline Swingle & 143 & 3 & 119 & 2 & 154 & 8 & 104 & 5 \\
\hline $\mathrm{CV} \%$ & 30 & & 32 & & 26 & & 33 & \\
\hline LSD 0.05 & 47 & & 40 & & 56 & & 42 & \\
\hline
\end{tabular}

${ }^{2}$ Effect of scion, stock, and scion $\times$ stock interaction significant $(P<0.01)$.

Table 3. Effect of stock on juice soluble solids content (SSC, percent) of four cultivars for 7-yearold trees (1988-89 season). ${ }^{\mathrm{z}}$

\begin{tabular}{|c|c|c|c|c|c|c|c|c|}
\hline \multirow[b]{3}{*}{ Rootstock } & \multicolumn{8}{|c|}{ Cultivar } \\
\hline & \multicolumn{2}{|c|}{$\begin{array}{c}\text { Hamlin } \\
\text { sweet orange }\end{array}$} & \multicolumn{2}{|c|}{$\begin{array}{c}\text { Valencia } \\
\text { sweet orange }\end{array}$} & \multicolumn{2}{|c|}{$\begin{array}{l}\text { Redblush } \\
\text { grapefruit }\end{array}$} & \multicolumn{2}{|c|}{$\begin{array}{l}\text { Murcott } \\
\text { tangor }\end{array}$} \\
\hline & SSC & Rank & SSC & Rank & SSC & $\overline{\text { Rank }}$ & SSC & Rank \\
\hline Carrizo & 11.2 & 11 & 12.3 & 5 & 9.2 & 12 & 12.9 & 8 \\
\hline Changsha & 11.2 & 13 & 12.0 & 9 & 9.8 & 3 & 13.3 & 5 \\
\hline Cleopatra & 11.3 & 10 & 11.8 & 11 & 8.9 & 13 & 12.7 & 11 \\
\hline Flying Dragon & 12.6 & 1 & 13.4 & 1 & 10.2 & 1 & 14.0 & 2 \\
\hline Jacobsen & 12.3 & 3 & 13.3 & 3 & 9.7 & 4 & 14.1 & 1 \\
\hline \multicolumn{9}{|l|}{ Koethen $\mathrm{X}$} \\
\hline Rubidoux & 11.7 & 7 & 12.5 & 4 & 9.4 & 9 & 13.0 & 6 \\
\hline Macrophylla & 9.7 & 16 & 10.3 & 15 & 7.8 & 16 & 12.1 & 14 \\
\hline Milam & 11.2 & 12 & 11.3 & 13 & 8.8 & 14 & 12.0 & 15 \\
\hline Morton & 11.8 & 5 & 12.0 & 10 & 9.6 & 5 & 12.9 & 10 \\
\hline Own-rooted & 11.8 & 6 & 11.8 & 12 & 9.4 & 8 & 13.9 & 3 \\
\hline Palestine & & & & & & & & \\
\hline sweet lime & 10.0 & 15 & 10.1 & 16 & 8.1 & 15 & 11.4 & 16 \\
\hline \multicolumn{9}{|l|}{ Rangpur $x$} \\
\hline Troyer & 10.6 & 14 & 10.3 & 14 & 9.3 & 11 & 12.1 & 13 \\
\hline Rubidoux & 12.4 & 2 & 13.3 & 2 & 9.5 & 6 & 13.6 & 4 \\
\hline Rusk & 11.9 & 4 & 12.2 & 6 & 10.0 & 2 & 12.2 & 12 \\
\hline Sour orange & 11.6 & 9 & 12.1 & 8 & 9.3 & 10 & 12.9 & 9 \\
\hline Swingle & 11.6 & 8 & 12.1 & 7 & 9.5 & 7 & 12.9 & 7 \\
\hline $\mathrm{CV} \%$ & 3.4 & & 4.0 & & 2.9 & & 3.7 & \\
\hline LSD 0.05 & 0.56 & & 0.68 & & 0.38 & & 0.68 & \\
\hline
\end{tabular}

'Harvest dates: 'Hamlin', 16 Feb. 1989; 'Valencia', 30 Mar. 1989; 'Redblush', 16 Feb. 1989; 'Murcott', 15 Feb. 1989. Effect of scion, stock, and scion $\times$ stock interaction significant $(\mathrm{P}<0.01)$.

from this season were used for comparison of fruit quality and yield potential. A severe freeze in Dec. 1989, when trees were 8 years old, killed most of the trees and terminated the experiment.

Tree size. Canopy volume for 7-year-old trees varied substantially among cultivars. 'Redblush' grapefruit trees were the largest (average $7.8 \mathrm{~m}^{3}$ of canopy per tree), orange trees were intermediate ('Hamlin', $6.6 \mathrm{~m}^{3}$; 'Valencia', $\left.6.1 \mathrm{~m}^{3}\right)$, and 'Murcott' trees were the smallest $\left(4.3 \mathrm{~m}^{3}\right)$. Grapefruit trees were larger than the $6.8 \mathrm{~m}^{3}$ containment size, oranges very close, and 'Murcott' trees had not reached it. Trees larger than containment size resulted from regrowth following hedging and topping that occurred before trees were measured.

Rootstock significantly affected tree size (Fig. 1). Trees on Flying Dragon were generally the smallest and those on sour orange the largest. Stocks generally considered vigorous in Florida (Castle et al., 1989), including Palestine sweet lime and Macrophylla, produced some of the larger trees. Trees on Swingle and sour orange are generally considered intermediate in vigor, but they were among the largest in this experiment. The greater cold tolerance of trees on sour orange and Swingle may have helped their relative performance during the winter freezes. Average tree height and trunk diameter (data not shown) were closely related to canopy volume $\left(r^{2}=0.82, P<0.01\right.$ and $r^{2}=$ $0.79, P<0.01$, respectively).

Yield. Cumulative yield for the first 4 years of production (tree age 5 to 8 years) also varied considerably among scion and stock combinations, ranging from $46 \mathrm{t} \cdot \mathrm{ha}^{-1}$ for 'Murcott' tangor on Macrophylla to 233 tha' for 'Redblush' grapefruit on Koethen $\times$ Rubidoux (Table 2). Carrizo, Swingle, and sour orange rootstock, which are commonly used in Florida, performed well with most scion cultivars in this experiment, as did Koethen $\times$ Rubidoux and Morton. Some stocks performed very well with some cultivars, but poorly with others. For example, Palestine sweet lime proved satisfactory for oranges, but was a poor rootstock for 'Murcott'. 'Murcott' and grapefruit performed well on Changsha, but it was a poor stock for both orange cultivars. Cleopatra, another commercial stock in Florida, was satisfactory for 'Murcott' but ranked low for oranges and grapefruit.

Average annual yields over all cultivars were $7.5,19.6,60.2$, and $22.7 \mathrm{t} \cdot \mathrm{ha}^{-1}$ for the first 4 years of production, respectively. Yield increased rapidly during the first three seasons but was reduced during the 4th year (1989-90) by a late-spring frost in 1989. Largest yields were obtained during the 198889 season when trees were 7 years old. Because many trees had reached containment size by the 1988-89 season and because there were no negative weather factors, production for this season by the better scion/stock combinations provided an indication of yield potential for a planting at this density. Average yield for the trees on the three best rootstock for each cultivar for the 1988-89 season were 69, 64, 107, and 97 t.ha' for 'Hamlin', 'Valencia', 'Redblush', and 'Murcott', respectively. Crop loads appeared heavy but not excessive for the orange and grapefruit cultivars. The excessive crop load on 'Murcott' resulted in some tree collapse and could not be maintained on an annual basis.

Part of the effect of rootstock on yield was related to the effect of stock on tree size. A correlation of yield on canopy volume for 'Hamlin' resulted in $r^{2}=0.42, P<0.01$; 'Valencia', $r^{2}=0.54, P<0.01$; 'Murcott', $r^{2}=0.39, P<0.01$; and a nonsignificant correlation for grapefruit.

Fruit quality. Juice quality varied among cultivars because of the different characteristics of the four cultivars. Effects of stock on fruit quality were also expected and confirmed in this experiment. As with yield, the effect of stock varied among cultivars, resulting in a significant interaction of scion and stock

Average fruit size was affected by stock, but there was no consistent effect over cultivars (data not shown). Because fruit size of citrus is affected by crop load, stock may influence fruit size indirectly by affecting crop load. This was particularly evident for 'Murcott', where trees on sour orange had a heavy crop load and small fruit. The inverse was 


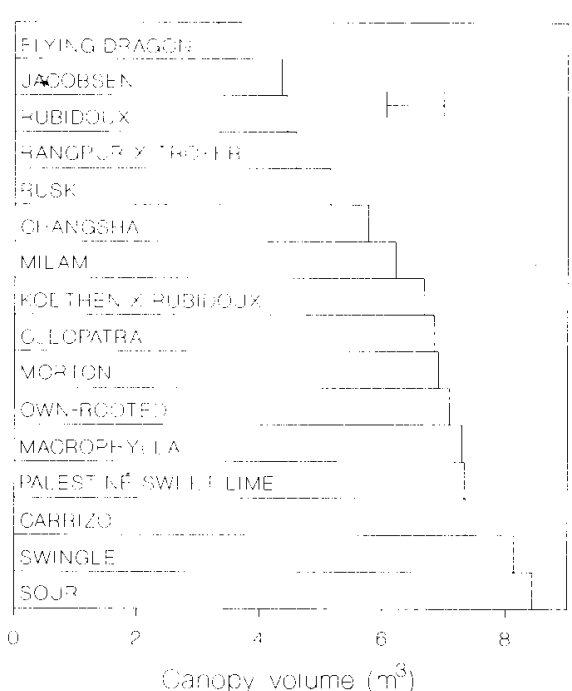

Fig. 1. Effect of stock on average canopy volume over all cultivars 7 years after planting. The bar denotes the LSD of $1.06(P=0.05)$.

true for 'Murcott' on Macrophylla.

The juice content of oranges ranged from $51 \%$ to $60 \%$ and for grapefruit from $56 \%$ to $63 \%$ (detailed data not shown). For these cultivars, juice content of fruit from trees on vigorous rootstock, such as Palestine sweet lime and Macrophylla, was low. Juice content was highest in fruit from trees on Swingle, sour orange, and Rusk rootstock. Juice content of 'Murcott' fruit from all rootstock was similar, ranging from $57 \%$ to $59 \%$.

Juice SSC was influenced by cultivar and rootstock (Table 3 ). Trees on vigorous stocks, such as Palestine sweet lime and Macrophylla, produced fruit with low SSC. Highest SSC was in fruit from trees on the trifoliate stocks Flying Dragon, Jacobsen, and Rubidoux. However, yield from trees producing fruit high in SSC was relatively low (Table 2 ). The value of citrus for processing is determined largely by the quantity of soluble solids produced per hectare, which is a function of yield, juice content, and juice total SSC. Thus, trees on stocks such as sour orange, Swingle, and the citranges, which produced good yield and juice of moderately high solids, were preferable to stocks with very high solids but low yield.

Potential for high-density citrus plantings. The results obtained in this experiment demonstrate the feasibility of high-density plantings for Florida citrus and show that selection of appropriate scion and stock combinations is an important ingredient in the success of such a planting. Among the cultivars, 'Murcott' appeared particularly suitable because of its upright growth habit and small trees, but it did not lose its propensity for alternatebearing despite the close spacing. Grapefruit, the most vigorous trees, produced well over the duration of this experiment, but confining tree size to the allocated space over a longer period might prove difficult. However, grapefruit trees bear more fruit internally than the other cultivars and, thus, may be productive even when subjected to rigid tree size control in a high-density planting.
Both orange cultivars were intermediate in rate of canopy development and appeared suitable for high-density planting.

Each scion cultivar is probably acceptable for use in a high-density planting, but rootstock selection will more significantly determine adaptability. For the duration of our experiment, rootstock of moderate vigor that induced relatively early bearing and provided good-quality fruit were best adapted to high-density planting. Rootstock such as sour orange, Swingle, and the citranges were particularly suitable in this experiment. They outperformed the less vigorous or dwarfing stocks that generally have been considered essential for high-density plantings and that have been used in experiments at other locations (Tachibana and Nakai, 1989; Hutton and Cullis, 1981).

Stocks that produced good yield and fruit quality and performed well for all four scion varieties included Carrizo, Koethen $\times$ Rubidoux, Morton, sour orange, and Swingle. Trees on Carrizo, sour orange, and Swingle were among the largest trees in this experiment, although sour orange and Swingle are generally considered intermediate in vigor. Trees on Koethen $\times$ Rubidoux and Morton were smaller, which makes these stocks good candidates for a high-density planting.

Changsha is an example of a rootstock that performed well with some cultivars and poorly with others. Yield and fruit quality were excellent for 'Redblush' grapefruit and 'Murcott', but oranges yielded poorly on Changsha. This combination of good fruiting and relatively small tree size suggests consideration of Changsha as a rootstock for grapefruit and mandarin cultivars in a high-density planting. Cleopatra, another mandarin stock, was satisfactory for 'Murcott', but yields were poor for the other cultivars. Close spacing did not enable Cleopatra to overcome its wellknown problem of poor productivity in the early years (Castle et al., 1989).

Macrophylla and Palestine sweet lime, generally considered very vigorous rootstock, produced large trees but poor fruit quality in this experiment. Yield of oranges was satisfactory but poor for grapefruit and 'Murcott'. Very vigorous stocks may not be appropriate for high-density plantings under Florida conditions, especially if similar performance can be obtained from trees on less vigorous stocks.

Dwarfing or less vigorous rootstock, including Flying Dragon, Jacobsen, and Rubidoux trifoliates, might seem desirable for high-density plantings, but they performed poorly in ours. Trees on these stocks grew slowly, were small, and had failed to reach containment size when the experiment was terminated. Fruit quality was excellent from trees on these stocks, but yield was generally poor for all cultivars. Although these were poor stocks in this experiment, they maybe considered in future high-density experiments based on their better performance at other locations (W.S.C., unpublished data). Their relative performance might have improved in an experiment of longer duration. Yield per hectare for dwarfing stocks could be improved by planting at even higher densities to compensate for smaller tree size (Fig. $1)$.

Own-rooted trees have been considered for high-density plantings because of their purported lower vigor, earliness to bearing, and ease and speed of production in comparison to budded trees. However, performance of own-rooted trees was not outstanding in this experiment. Tree size was average, fruit quality was good for 'Murcott' but average for the other cultivars, and yields were low.

The primary advantage of high-density planting is the rapid development of canopy bearing volume and yield per unit of land area. For citrus, most light interception and fruiting occur in the outer shell of canopy $\approx 1 \mathrm{~m}$ in depth, termed the "bearing" volume (Wheaton et al., 1978). Under optimal conditions, many citrus scion/stock combinations will develop a canopy $2 \mathrm{~m}$ in diameter and $2.5 \mathrm{~m}$ high in 3 to 5 years. For trees of these dimensions, the entire canopy theoretically should be bearing volume. The goal of rapid growth to containment size and early productivity was not realized in our experiment because of several freezes during the years following planting. Very early productivity probably could be improved by planting at high density. However, because of the rapid growth of canopy and yield potential of citrus grown under Florida's subtropical climate, plantings at moderate densities become highly productive at a relatively early age. Previous experiments with densities of 717 trees/ha (Koo and Muraro, 1982) and 890 trees/ha (Wheaton et al., 1986) achieved substantial productivity during the first 5 to 7 years.

In addition to rapid development of bearing volume, a high-density planting needs to have adequate bearing volume per unit of land area to provide a large production potential. Bearing volume at containment size for various planting systems can be calculated. Conventional hedgerow plantings with row spacings of 6 to $8 \mathrm{~m}$ and a tree height of 5 to $6 \mathrm{~m}$ develop $\approx 16,000 \mathrm{~m}^{3}$ of bearing volume per ha but require 10 or more years to reach containment size (Wheaton et al., 1978). Based on a bearing volume of 13,635 $\mathrm{m}^{3}$ at containment size for our high-density planting and a yield potential of $5.3 \mathrm{~kg} / \mathrm{m}^{3}$ of bearing volume established previously for oranges (Wheaton et al., 1978), production of $73 \mathrm{t} \cdot \mathrm{ha}^{-1}$ could be anticipated. Thus, the observed orange yields of 64 and $69 \mathrm{t} \cdot \mathrm{ha}^{-1}$ indicate a yield efficiency per unit of bearing volume similar for these and conventionally spaced trees. Maximum yields for oranges observed in this experiment were similar to those reported in other high-density plantings (Hutton and Cullis, 1981; Tachibana and Nakai, 1989). None of the experiments attained the production goal of $100 \mathrm{t} \cdot \mathrm{ha}^{-1}$ proposed by Cary (1981) for oranges, nor did yields exceed the 60 to $80 \mathrm{t} \cdot \mathrm{ha}^{-1}$ obtained from mature, moderately spaced plantings in Florida (Koo and Muraro, 1982).

High-density plantings in Florida may provide only marginal improvement in early productivity and appear to have no yield ad- 
vantage at maturity. Shorter trees in a highdensity planting would allow harvesting from the ground, but closer row spacings would require development of new fruit handling equipment. Tree densities $>1000$ trees/ha may provide little benefit over moderate densities of 350 to 900 trees/ha.

\section{Literature Cited}

Castle, W.S., D.P.H. Tucker, A.H. Krezdorn, and C.O. Youtsey. 1989. Rootstock for Florida citrus. Univ. of Florida Ext. Bul. SP42.

Cary, P.R. 1981. Citrus tree density and pruning practices for the 21st Century. Proc. Intl. Soc. Citriculture. 1:165-168.

Hutton, R.J. and B.R. Cullis. 1981. Tree spacing effects on productivity of high density dwarf orange trees. Proc. Intl. Soc. Citriculture 1:186190.

Koo, R.C.J. and R.P. Muraro. 1982. Effects of tree spacing on fruit production and net returns of 'Pineapple' oranges. Proc. Fla. State Hort. Soc. 95:29-33.

Tachibana, S. and S. Nakai. 1989. Relation between yield and leaf area index in different planting densities under different cultural treat- ments in Satsuma mandarin (Citrus unshiu Marc. var. praecox) tree. J. Jpn. Soc. Hort. Sci. 57:561-567.

Wheaton, T.A., W.S. Castle, D.P.H. Tucker, and J.D. Whitney. 1978. Higher density plantings for Florida citrus-concepts. Proc. Fla. State Hort. Soc. 91:27-33.

Wheaton, T.A., J.D. Whitney, W.S. Castle, and D.P.H. Tucker. 1986. Tree spacing and rootstock affect growth, yield, fruit quality, and freeze damage of young 'Hamlin' and 'Valencia' orange trees. Proc. Fla. State Hort. Soc. 99:29-32. 